\title{
EFFECTS OF ACID DEPOSITION ON THE
}

EMERGENCE OF BLACKFLIES

(DIPTERA: SIMULIIDAE)

OVER 50 YEARS FROM

\section{ALGONQUIN PARK STREAMS}

JULY 1992 



\title{
EFFECTS OF ACID DEPOSITION ON THE EMERGENCE OF BLACKFLIES (DIPTERA: SIMULIIDAE) OVER 50 YEARS FROM ALGONQUIN PARK STREAMS
}

\author{
Report Prepared By: \\ C.M. Chmielewski ${ }^{1}$ \\ Trent University \\ Peterborough, Ontario K9J 7B8 \\ and \\ R.J. Hall ${ }^{2}$ \\ Ontario Ministry of the Environment \\ Bellwood Acres Road \\ P.O. Box 39, Dorset, Ontario P0A 1E0
}

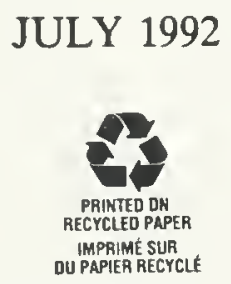

Cette publication technique n'est disponible qu' en anglais.

Copyright: Queen's Printer for Ontario, 1992

This publication may be reproduced for non-commercial purposes with appropriate attribution. 

EFFECTS OF ACID DEPOSITION ON THE EMERGENCE OF BLACKFLIES (DIPTERA: SIMULIIDAE) OVER 50 YEARS FROM ALGONQUIN PARK STREAMS

\author{
${ }^{1}$ Present address: \\ P.O. Box 273 \\ Harrisville, Pennsylvania, U.S.A. \\ 16038 \\ ${ }^{2}$ Author to whom reprint \\ requests should be directed
}





\begin{abstract}
Studies on emergence of blackfly populations conducted in Mud Creek and Costello Creek in Algonquin Park, Ontario, Canada, over a period of 50 years were analyzed to assess the effects of long-term anthropogenic acidification. The headwaters of Mud Creek are currently experiencing $\mathrm{pH}$ depressions to 5.1 to 4.9 during snow-melt whereas $\mathrm{pH}$ depressions downstream in Mud Creek and throughout Costello Creek are less severe (to $\mathrm{pH}$ 5.6-5.8) compared to summer and autumn values of about 6.4. Since the time of the earliest collections, the total number of blackflies emerging has increased at MC1 and MC2, the most severely acidified sites, while emergence remains unchanged in all the less acidified sites. Large fluctuations from year to year in the emergence densities of many individual species were observed at all sites, making it difficult to determine which species may increase or decrease due to elevated acidity.
\end{abstract}




\section{TABLE OF CONTENTS}

Abstract ................................

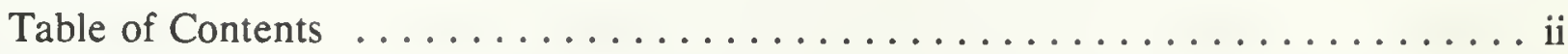

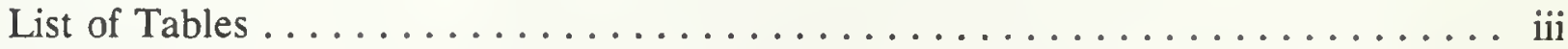

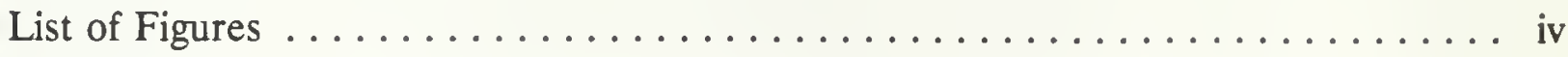

Introduction . . . . . . . . . . . . . . . . . . . . . . . . . . . . . 1

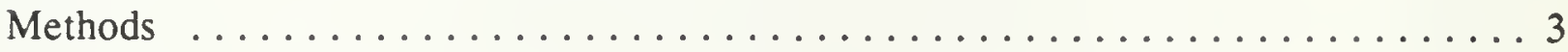

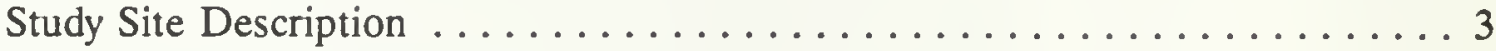

Chemical and Physical Measurements ................. 4

Emergence Traps ............................. 4

Emergence Trap Comparison . . . . . . . . . . . . . . . 7

Results ...............................8

Chemical and Physical Parameters $\ldots \ldots \ldots \ldots \ldots \ldots \ldots \ldots$

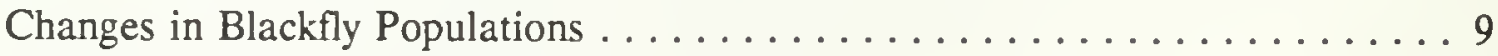

Changes in Species Composition . . . . . . . . . . . . . . . 10

Discussion . . . . . . . . . . . . . . . . . . . . . . 11

Acknowledgements . . . . . . . . . . . . . . . . . . . . . . 15

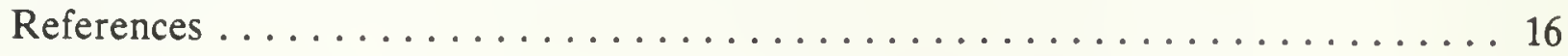




\section{LIST OF TABLES}

Table 1

Mean density of black flies collected to compare the trap type used in the 1937-47 emergence studies (cage) with the trap type used in the 1984-86 studies (cone).

Table 2

Total numbers (mean number $/ \mathrm{m}^{2} \pm$ S.E.), percent composition (in parentheses) and diversity indices for 14 species of blackflies collected in emergence traps in Costello Creek (CC1) from 1937-1986.

Table 2

Total numbers (mean number $/ \mathrm{m}^{2}$ ), percent composition (in parentheses) and diversity indices for 13 species of blackflies in Costello Creek, Station 2 (CC2) from 1946-75.

Table 4 Total numbers (mean number $/ \mathrm{m}^{2}$ ), percent composition (in parentheses) and diversity indices for 18 species of blackflies collected in emergence traps from Mud Creek, Station 3 (MC3). 


\section{LIST OF FIGURES}

Figure 1 Map of study sites on Costello Creek and Mud Creek, Algonquin Park, Ontario. The greatest $\mathrm{pH}$ depressions are presently occurring in Mud Creek 1. The $\mathrm{pH}$ depressions are intermediate in severity in Mud Creek 2 and 3 and least severe in Mud Creek 4 and Costello Creek (CC1 and CC2).

Figure 2

The three emergence traps used for blackfly collections from Costello Creek and Mud Creek, Algonquin Park, Ontario. a) "Cage Trap" used by Ide (1940), Sprules (1947) and Davies (1950) and others between 1937-47. b) "Pyramid Trap" used by Hayton (1979) in 1975. c) "Cone Trap" used by R.J. Hall in 1984-86 (see also Wetzel and Likens 1991, page 192). See text for details of construction and operation.

Figure 3

pH measurements (1984-86) from Costello Creek and Mud Creek, Algonquin Park, Ontario. Data from older studies: Costello Creek 11938 range 6.2-6.8 (Ide, 1940). Mud Creek 1938-41 range 6.1-6.7 (all sites); 1938 reading average (17 June - 9 Sept) site $1,6.1$; site 2, 6.2; 12 August 1938, one reading site 4, 6.5 (Sprules, 1947).

Figure 4

Discharge readings (1984-86) from Costello Creek and Mud Creek, Algonquin Park, Ontario. No discharge data is available from Costello Creek 1937-47. Mud Creek 1938 discharge data: average of six readings (17 June - 9 Sept) site $12.8 \mathrm{l} / \mathrm{s}$, site $214.2 \mathrm{l} / \mathrm{s} ; 12$ August one reading site 4 (station 6) $113.3 \mathrm{l} / \mathrm{s}$, (station 7) $90.6 \mathrm{l} / \mathrm{s}$ (Sprules, 1947).

Figure 5

Temperature readings (1984-86) from Costello Creek and Mud Creek, Algonquin Park, Ontario. Data from early studies: Costello Creek 1937$38,1940,1946-47$ range (both sites) $3^{\circ} \mathrm{C}$ (Ide, 1940); Mud Creek 1938-41 
average Mud Creek 1: $16^{\circ} \mathrm{C}$, Mud Creek 2: $13^{\circ} \mathrm{C}$, Mud Creek 3: $16^{\circ} \mathrm{C}$, Mud Creek 4: $17^{\circ} \mathrm{C}$ (Sprules, 1947).

Figure 6a, 6b Total numbers of blackflies emerging per $\mathrm{m}^{2}$ per year in Costello Creek (CC1 and 2) and Mud Creek (MC1-4), Algonquin Park, Ontario. Data shown between 1937 and 1947 represent the total number of blackflies emerging into one square yard cage trap per site (except for the two years (1939-40) of data for MC4 where two traps were used). All 1937-47 data are taken from Ide 1940, Sprules 1947 and Davies 1950 except for the MC3, 1947 point from D.M. Davies collections (unpubl.). The 1975 data represents the mean and standard error of the number of blackflies emerging into two pyramid traps in CC1 and one trap in CC2. The 198486 data represents the mean and standard error of the numbers of blackflies emerging into 8 to 15 cone traps. The Mud Creek data for the years 1984-86 were truncated to match the collection dates of the 1938-40 collections (Mud Creek 1: 1 June-11 September; Mud Creek 2 and 3: 1 June-31 August; Mud Creek 4: 6 June-31 August). Therefore the Mud Creek data is not strictly comparable from site to site. 



\section{INTRODUCTION}

The effects of lowered stream pH on the abundance of mayflies, stoneflies, caddisflies and chironomids are well documented (e.g., Bell 1971, Sutcliffe and Carrick, 1973, Hall et al. 1980, Raddum and Fjellheim 1984, MacKay and Kersey 1985 and Giberson and MacKay, 1991). Although our knowledge of the effects of episodic pH depressions on blackflies (Diptera: Simuliidae) is decidedly scarce, the Simuliidae are generally thought to be a hardy family, capable of tolerating adverse conditions that extirpate more sensitive biota (Adler 1988). Although several factors, including depth, substrate, current velocity, current flow, discharge, day length, food supply and temperature, contribute to blackfly distributions, $\mathrm{pH}$ is typically the most significant (see Ross and Merritt 1987 for review). The blackfly's ability to dominate the fauna of acidified streams (Sutcliffe and Carrick 1973, Hildrew et al. 1984, Stoner et al. 1984, Simpson et al. 1985 and Sharpe et al. 1987) may be indicative of their greater tolerance of acidity compared to their stream cohabitants (Hall et al. 1980, Bernard et al. 1990 and Hopkins et al. 1989). Whether the correlations between the organisms' distributions and $\mathrm{pH}$ are direct, indirect or fortuitous remains contentious (Ross and Merritt 1987), as the synergistic effects of physical or chemical factors may not be readily dismissed.

Because the loss or gain of a species usually precedes changes in other ecosystem functions, such as productivity, certain species may be more sensitive early warning indicators of ecosystem stress (Gorham et al. 1984 and Schindler 1987). Although different species may exhibit differential responses to specific stresses (Resh and Unzicker 1975), few investigations have, however, identified blackflies to species during the course of a study (Stoner et al. 1984, Simpson et al. 1985 and Hall et al. 1988). Therefore, our understanding of the impact of acidity on blackflies is incomplete.

Clearly there is a need to determine if the preference of blackflies for acidic streams is caused solely by the difference in $\mathrm{pH}$ or by combinations of other physical, chemical and biological factors that are unique to each stream. Because both abiotic and biotic components of natural ecosystems fluctuate naturally to varying degrees over time (Gorham 
et al 1984), it is difficult to separate natural spatial or temporal disturbances from the additional effects of such anthropogenic stresses as elevated acidity. Therefore, long-term (>10 years) environmental monitoring must be used to establish meaningful baseline trends in population and ecosystem dynamics (Likens 1983, Gorham et al. 1984 and Strayer et al. 1986). Without such baselines, the impact of anthropogenic stresses cannot be determined.

Several studies on emergence of insect communities from two low-alkalinity streams, Costello Creek and Mud Creek (Algonquin Park, Ontario), have provided such a long-term baseline data set. The first studies were begun in 1937 by Ide (1940) and continued in collaboration with Sprules (1947) and Davies (1950) and others until 1947. The main objectives then were to determine the life history patterns of various taxa that were food sources for speckled trout and were of economic importance to humans and birds (biting flies, such as blackflies, deerflies and horseflies). Adult insects were collected daily from emergence traps at several sites in both creeks from early spring until the early or late autumn for nine years (1937-1947). In 1975, Hayton (1979) studied the life history of blackflies by collecting larvae and adults in Costello Creek only from May to September.

Although historical monitoring of $\mathrm{pH}$ of rain in North America was sporadic, Cogbill (1976) has determined that the $\mathrm{pH}$ of precipitation in New York state was not less than 5.6 before 1930, but that by 1955 a large area of north-eastern North America was receiving acid precipitation with a $\mathrm{pH}$ of less than 5.6 (acid precipitation). Therefore, it is likely that Costello and Mud Creeks began receiving severely acidic precipitation some time between the conclusion of the 1937-47 studies but before the 1975 studies.

To determine whether significant, long-term changes in blackfly communities can be correlated with this acidification, insect emergence collections were made over a three year period (1984-86) in both creeks (Hall and Ide 1987) from the same sites studied approximately 50 years ago. In this study, we compare the current and historical collections of species assemblages from the streams. 


\section{METHODS}

\section{Study Site Description}

Costello Creek (Fig. 1) is a small, permanent stream flowing from Costello Lake to

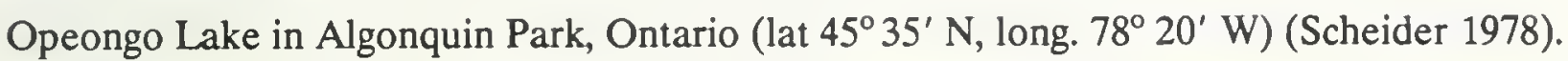
The physical characteristics of the stream remained similar to those described in Davies (1950) with the exception of the instalment of two culverts that replaced a wooden bridge upstream from the sampling sites sometime between 1947 and 1975 (Hayton 1979).

Mud Creek is located close to Costello Creek near the southeast boundary of Algonquin Park, Ontario (lat $45^{\circ} 33^{\prime} \mathrm{N}$, long. $78^{\circ} 15^{\prime} \mathrm{W}$ ) (Fig. 1). It arises as the outlet of a small pond $\left(0.03 \mathrm{~km}^{2}\right)$ and meanders approximately $13 \mathrm{~km}$ in a generally southerly direction connecting several small lakes. The physical characteristics of Mud Creek also remain unchanged since Sprules (1947) described it (Hall and Ide 1987).

Presently, these low-alkalinity streams (Costello and Mud Creek, Fig. 1) are subjected to inputs of sulphuric and nitric acids in rain and snow at a monthly mean volume weighted pH of 4.3 (monthly range 3.97-4.75; Chan et al. 1983, Ontario Ministry of the Environment 1984, 1986). Both streams are underlain by granitic bedrock and are poorly buffered (Davidson et al. 1985) and are typical of many streams on the Canadian Shield that are susceptible to acidic deposition and subsequent $\mathrm{pH}$ depressions during snowmelt and rain storms. However, Costello Creek arises as the outflow of a relatively large lake (Costello Lake, $0.34 \mathrm{~km}^{2}$ ) that is able to partially neutralize incoming acids (Fig. 1). Conversely, at the study sites in Mud Creek located close to its origin, the potential for strong acids to be neutralized is less. As a result, these sites presently experience more pronounced $\mathrm{pH}$ fluctuations during spring runoff than do the sampling sites downstream, or at either of the sites in Costello Creek. 


\section{Chemical and Physical Measurements}

Temperature and discharge were monitored weekly from early May to early October in 1984-86 in Costello Creek and Mud Creek. In addition, for the duration of the study, water samples were collected weekly (monthly during winter and daily during snowmelt) and analyzed, for $\mathrm{pH}$, oxygen, alkalinity, inorganic monomeric aluminum, dissolved organic carbon (DOC), magnesium, sulphate and nitrogen, (LaZerte 1984, Locke and Scott 1986). Discharge, $\mathrm{pH}$, temperature and oxygen are presented here. All other parameters are reported by Findeis et al. (1992).

\section{Emergence Traps}

The "cage" trap (Fig. 2) was used for all emergence collections by Ide and his students and covered a total stream area of $0.84 \mathrm{~m}^{2}$. Pyramid-shaped emergence traps (Fig. 2) were used by Hayton (1979) for his emergence collections of 1975 and covered $0.25 \mathrm{~m}^{2}$ of the stream bottom. Construction details of the cage and pyramid-shaped emergence traps can be found in Ide (1940) and Hayton (1979), respectively.

Cone traps (Fig. 2) were used for the emergence collections made in 1984-86. These were constructed with $1.4 \mathrm{~mm}$ fibre glass window screening glued into a cone shape. Its base was then glued to a ring ( $30 \mathrm{~cm}$ diameter) of $12 \mathrm{~mm}$ PVC tubing. A $7 \mathrm{~cm}$ straight length of 40 mm PVC tubing protruded through the apex of the cone, then through a hole in the bottom of a $1 \mathrm{~L} \mathrm{Nalgene} \mathrm{bottle.} \mathrm{Silicone} \mathrm{sealant} \mathrm{was} \mathrm{used} \mathrm{to} \mathrm{seal} \mathrm{any} \mathrm{gaps} \mathrm{between} \mathrm{the} \mathrm{tubing} \mathrm{and}$ the bottle so that a small amount of $70 \%$ ethanol could be contained by the bottle without leakage. A string attached to the top of the bottle and an overhead support suspended the trap over the stream so that the base floated on the water surface. Insects emerging into the trap migrated to the apex of the funnel, then into the collecting bottle where they eventually fell into the alcohol. Collections were made weekly. The total area of stream covered by a cone trap was $0.07 \mathrm{~m}^{2}$. 
Between 1937 and 1943, F.P. Ide and his students maintained a cage trap covered with window screen (15 mesh per inch) in Costello Creek. The cage was located in the rapids $75 \mathrm{~m}$ downstream from a beaver dam at the outlet (Fig. 2) (Ide 1940, Davies 1950). This site will be referred to as $\mathrm{CC} 1$ for this study. Ide (1940) called this location Costello Lake No. 1. Collections were made from May to September in all years. Cage traps were maintained by Knapp (unpubl. data, Davies 1950) for one week (24-30 May) and by Savage (1949) for one week (22-31 July) in 1944. In 1945, Savage (1949) made collections starting on 14 June, 1945 (see Davies 1950). In both years, peak blackfly emergence was missed. The entire stream was sprayed with DDT in June of 1944 (Davies 1950). Although the stream appeared to have recovered from the spraying (Hall and Ide 1987), the 1944-45 collections were not included in this study. In 1946 and 1947, Davies (1950) continued emergence collections in Costello Creek at a site further upstream in the riffles just below the bridge. This site will be referred to as CC2 (Fig. 1). The smaller mesh (20 mesh per inch) was used on the cage. Collections were made from May to September.

In 1975, Hayton (1979) used six pyramid traps (Fig. 2) placed at intervals over the course of Costello Creek. One trap was placed in the riffle below the road (CC2) (Fig. 1) and could therefore be used in comparison with the data from 1946-47. Two more traps were both placed in the rapids farther downstream in the same area as the cages of 1937-43 (CC1).

Between 1984-86, ten cone traps were randomly placed in the rapids (CC1) for this study. Weekly collections were made from May to October in each year. These collections were compared to both the $1937-43$ and the 1975 collections.

Mud Creek collections from four sites were used. The first site (MC1) is the same one as the Sprules (1947) Station 1 and was located $50 \mathrm{~m}$ below the first small beaver dam along a rocky channel $1 \mathrm{~m}$ wide (Fig. 1). The flow here is intermittent; the stream dries up in the summer of some years. Dense riparian vegetation provides almost total shade in summer. The second site, referred to as MC2 [Sprules' (1947) Station 2], is located in a rocky riffle approximately $150 \mathrm{~m}$ downstream from Mud Creek 1 . The outflow from a sphagnum bog 
$50 \mathrm{~m}$ upstream provides a permanent flow. This area of the stream is not completely shaded. The third site, subsequently referred to as MC3 [Sprules' (1947) Station 3a, Davies' (1950 and unpubl.) Smith's Lake Inlet], is located $100 \mathrm{~m}$ from Castalia Lake in the centre of a rocky riffle (Fig. 1). The flood channel is approximately $2.5 \mathrm{~m}$ wide. The fourth site, subsequently referred to as MC4, covers the section of stream between station 6 and station 7 in Sprules (1947). Station 6 (Sprules 1947) was several hundred metres downstream from $\mathrm{MC} 3$ in the centre of a long gravel riffle. The flood channel is approximately $5 \mathrm{~m}$ wide and the area is unshaded. Station 7 (Sprules 1947) was $60 \mathrm{~m}$ downstream from station 6. Here the current is reduced and the bottom sandy. The flood channel is $4 \mathrm{~m}$ wide and shaded by riparian vegetation (Sprules 1947).

Between 1938 and 1940, all collections in Mud Creek were made by Sprules using one cage trap per site. Collections were made daily from early June to early September in most years. Collections were made by D.M. Davies (unpubl.) using one cage trap at MC3 from 4 May to 23 June, 1947.

In 1984-86, ten to fifteen cone traps were set randomly at each Mud Creek site from early May to early October in each year, except at MC4 where collections did not begin until 1985. The traps were cleared weekly. Since the time between the start and finish dates for emergence collections was longer in each year of the 1984-86 studies compared to the 193840 studies, the collection dates and data were truncated to match the collection dates of the latter for each site. Thus, the collection periods will not be the same from site to site, but they will be from year to year for each site.

All blackflies were identified to species except for the 1938-40 Mud Creek collections of Sprules (1947), which were identified to family only and were not available to the authors. The 1937-47 collections from Costello Creek (Ide 1940 and Davies 1949, 1950) and the MC3 collections of Davies (unpubl.) were available for identification or re-identification where necessary. Since 1938 to 1947 or 1975 specimens were not cytotypically separated, there was no attempt to do so with the $1984-86$ specimens. 
Before analysis, all of the emergence data were standardized to number per $\mathrm{m}^{2}$. In addition, the numbers of blackflies were corrected for an unnatural increase due to the influx of a particularly vicious species (Simulium venustum) attempting to feed on the collector through the mesh of the cage trap (see Davies 1950). Non-parametric statistical analyses were used (Mann-Whitney "U" Test and the Wilcoxon Signed Rank Test) for trap comparisons (see below) due to the low number of sampling units (as few as three).

\section{Emergence Trap Comparison}

The relative trapping efficiencies of cages and cone traps were tested in a series of experiments conducted in 1985-86. In 1985, three cage traps were set up for approximately one week in both Costello and Mud Creeks in the same area of stream as the cone traps. The cage traps were cleared daily (following procedures in 1937-42), while the cone traps were cleared weekly. In 1986, three cage traps were placed directly over three of the smaller cone traps in Mud Creek. For analysis, the area of the cone trap was subtracted from the area of the cage trap to derive the net area of the cage trap. Five of these trappairs were set up in Costello Creek. The trap-pairs were set out for 28 days and cleared daily.

The cage traps located over similar areas of the stream in 1985 caught comparable numbers of blackflies as cone traps in both Costello Creek $(P=0.13$, alpha $=0.05)$ and Mud Creek $(P=0.11$, alpha $=0.05)$ (Table 1$)$. In 1986 , although the number of blackflies caught by the cone traps inside the cage traps was not significantly different from those caught by the cone traps outside the cages in Costello Creek $(P=0.62)$, the cone traps inside the cage traps caught significantly fewer blackflies than their corresponding cage traps $(\mathbf{P}=0.04)$. The opposite was true in the trap-pair comparisons in Mud Creek. The cones inside the cage caught significantly fewer blackflies than the cones outside the cages $(P=0.03)$. When the specimens caught in the 1986 Mud Creek trap comparisons were identified, the mean number of species of blackflies caught in the cones was $5.7 \pm 1.15$. The cages caught a mean of $9.7 \pm 0.58$ species. Essentially, any species caught in the cone traps were caught in its corresponding cage, but the cage traps were more likely to catch the less abundant 
species. However, the cone traps inside the cage traps in Mud Creek caught similar numbers of blackflies $(P=0.29)$.

In the 1986 comparisons, the placement of one trap inside the other introduced the disadvantages of 1) additional disturbance due to daily, rather than weekly collections, 2) the double-shading effect under the cone traps in the cages that may have induced an avoidance reaction on emerging insects (Scott and Opdyke 1941, Kimmerle and Anderson 1967, Boerger 1981 and Davies 1984) more pronounced than if only the cone trap were present, and 3) a smaller than normal area for the cage trap (since the area of the cone was subtracted from it) which could lead to the collection of certain species by the cone and not by the cage trap. However, this design in 1986 offered the advantage of similarity of stream bottom sampled in a heterogeneous environment. The comparison in 1985 was preferred because of the greater similarity to actual field operations for collecting insects routinely. Thus, after normalizing for area $\left(\# / \mathrm{m}^{2}\right)$, the results in 1985 showed that total numbers collected in daily collections in the cage traps could be compared directly with those captured continuously for a week using cone traps.

\section{RESULTS}

\section{Chemical and Physical Parameters}

Costello Creek had pH depressions in the years 1984-86 with a spring/summer range of 5.77 to 6.48 and annual mean of $6.19 \pm$ S.E. $=0.19$ (Fig. 3). In Mud Creek, MC1, the site closest to the source, experienced the greatest $\mathrm{pH}$ depressions from a mean of 6.30 in summer to as low as 4.90 in early spring (annual mean $=5.75 \pm 0.35$ ). MC2 and MC3, farther downstream, also experienced annual $\mathrm{pH}$ depressions, although not as severe, ranging from 5.09 to 6.54 (annual mean $=6.10 \pm 0.39$ ) and 5.11 to 6.43 (annual mean $=$ $6.10 \pm 0.22$ ), respectively. The $\mathrm{pH}$ fluctuations observed at MC4 are more similar to those of Costello Creek with ranges of 6.79 to 5.56 (annual mean $=6.35 \pm 0.26$ ) (Fig. 3). Data from the early studies on $\mathrm{pH}$ can be found in Ide (1940) and Sprules (1947), but for summer only. 
The 1984-86 discharges at Costello Creek ranged between 7.6 to 1780 1/s (Fig. 4). Ranges for MC1 to MC4 were 0.250 to $450,0.5$ to $492,3.73$ to 1190 and 44.7 to $2290 \mathrm{l} / \mathrm{s}$, respectively. High discharge in the spring of 1985 was observed in both creeks at all study locations.

Range in temperature for $\mathrm{CC} 1$ was 2 to $29^{\circ} \mathrm{C}$ (Fig. 5). At MC1 the temperature range was 0.5 to 31 , at MC2 1 to 24 and at MC3 and MC4 0.5 to $27^{\circ} \mathrm{C}$. The oxygen range for $\mathrm{CC} 1$ was 5.4 - $13.2 \mathrm{mg} / \mathrm{L}$. Ranges for MC1 to MC4, respectively, were 1.7-13.6, 3.6-13.8, 2.8-12.7, and $6.5-13.5 \mathrm{mg} / \mathrm{L}$.

\section{Changes in Blackfly Populations}

\section{Changes in Total Numbers}

The most extensive series of collections were those at $\mathrm{CC} 1$ in which the total numbers were available for 11 years. Total numbers of blackflies from 1937-43 fluctuated around a midrange that is consistent with both the 1975 and 1984-86 data, all years being within two orders of magnitude (Fig 6a). Total numbers from CC2 for all four years also show relatively constant blackfly emergence densities in pre- and post-acidification years, all within one order of magnitude.

There were fewer years (two years at most) of early data for any of the sites at Mud Creek (Fig. 6b). Consequently, with the yearly fluctuations the population baseline is more difficult to discern. At MC1 blackfly density dropped two orders of magnitude from 1940 to 1941 (Fig. 6b). This decline is the greatest difference between any two adjacent years at any site. The 1984-86 data does not exhibit this degree of variability. All three years are well within one order of magnitude but their standard errors are greater than those for any other site. It is clear that the numbers of blackflies that emerged in $\mathrm{MC1}$ are greater in the postacidification studies (Fig. 6, mean $=4,522-6,414 \mathrm{~m}^{-2} 1984-86$ ) than in the pre-acidification studies (range $=2-131 \mathrm{~m}^{2-}, 1938-39$ ) relative to the other sites. With only one year of MC2 pre-acidification data $\left(2 \mathrm{~m}^{-2}\right)$ (Fig. $6 \mathrm{~b}$ ) available it is difficult to determine a baseline 
for this site. The two years of early data available for MC3 (1939, 1,804 $\mathrm{m}^{-2}$ (Fig 6b); and 1947 1,032 $\mathrm{m}^{-2}$ (Table 4)) showed variable densities of emergent blackflies. The 1984-85 data indicated relatively no change in the average density ( $400 \mathrm{~m}^{-2}$ of blackflies at MC3). Similarly, comparisons of two years of collections in MC4 (1939, mean $=90$ and 1940, mean $=140 \mathrm{~m}^{-2}$ ) with numbers from two traps each in the early studies showed roughly similar densities to the $1985-86\left(135-211 \mathrm{~m}^{-2}\right)$ collections (Fig. 6b).

Note that in 1985, all of Mud Creek's sites had a lower density of emerging blackflies (Fig. 6), perhaps likely due to the high discharge rate that year (Fig. 4). Finally, considering only the 1984-86 data from Mud Creek, there is a definite increase in blackfly densities moving from the downstream sites (MC4) to the increasingly acidic upstream sites (MC1). Overall, the total number of blackflies in 1939 were at least two orders of magnitude less than the 1984-86 total numbers.

\section{Changes in Species Composition}

Of a total of 15 species occurring at $\mathrm{CC} 1,8$ species were characterized by abundances that were relatively constant proportions of the total over all years and are considered rare relative to the total collected blackfly community (Table 2). The other seven species alternated numerical dominance with no one species dominating for more than two years. These seven species were Cnephia dacotensis (Dyan and Shannon), Simulium euryadminiculum Davies, S. venustum Say complex, S. verecundum Stone and Jamnback complex, Stegopterna mutata (Malloch) Prosimulium fuscum Syme and Davies and P. mixtum Syme and Davies. In some of these species, the difference between consecutive years was as high as $70 \%$ ( $C$. dacotensis and $P$. fuscum). The only visible temporal trends may be the consistently higher proportions of St. mutata in 1984-1986 over the 1939-1943 and 1975 collections. Also S. euryadminiculum, one of the most dominant species in 1939-1941, decreased in its proportion, until in 1984-1986 none were caught. The Shannon-Weiner diversity indices were also higher on average in the 1975 and 1984 to 1986 collections than they were in 1939 to 1943 collections. 
The three years of collections at CC2 (1946, 1947 and 1975) showed essentially the same variability as did the $\mathrm{CC} 1$ collections (Table 3 ). Of 13 species, three alternated numerical dominance ( $S$. venustum, $S$. verecundum and $S$. vittatum Zetterstedt complex). The only detectable temporal trend may be the increase of the proportion of $P$. fuscum from $0 \%$ in 1946 and <1\% in 1947 to $23 \%$ in 1975 . The 1975 Shannon-Weiner diversity indices are higher in 1975 than in 1946 or 1947.

The three years of collections from MC3 show the most consistency over time (Table 4). There were 13 species with S. venustum dominant in 1947, St. mutata dominant in 1985 and S. verecundum dominant in 1985. S. venustum shows the only possible temporal trend by decreasing from 64\% in 1947 to 18 and $17 \%$ in 1984 and 1985, respectively. As in the Costello Creek sites, the Shannon-Weiner indices of diversity are higher in 1985 and 1986 than they were in 1947.

\section{DISCUSSION}

It is clear that, with all else being equal, $\mathrm{pH}$ depressions in Mud Creek have most likely directly or indirectly precipitated the observed increases in blackfly emergent densities where $\mathrm{pH}$ depressions were greatest. In lower reaches of the stream (MC3 and MC4) and in the control stream (Costello Creek) where $\mathrm{pH}$ depressions are less significant, blackfly densities have remained essentially unchanged for up to 50 years.

The observed trend of increased blackfly abundance upstream with decreased $\mathrm{pH}$ in Mud Creek (taken from the 1984-86 data) is in agreement with the results of stream surveys that have reported higher numbers of blackflies in more acidified headwaters (Minshall and Minshall 1978). Although there are no other surveys known which have monitored blackfly emergence at the same sites before and after acidification, many investigators comparing different streams have reported an increase in blackflies with increased acidity. Sutcliffe and Carrick (1973), studying mountain streams in the English Lake District, reported that streams with a $\mathrm{pH}$ of less than 5.7 were characterized by 13 abundant taxa that included Simulium spp. In a survey of four streams with mean annual $\mathrm{pH}$ of 4.8, 5.1, 5.2 and 6.1 
Hildrew et al. (1984) concluded that, although invertebrate species richness dramatically decreased in the more acidic streams, the densities of Simuliidae were highest there, with only a few blackflies in the higher pH streams. Stoner et al. (1984) found an approximately equal distribution of several species of blackflies in several Welsh streams with $\mathrm{pH}$ values ranging from 4.7 to above 6 , whereas many other invertebrate taxa were not present at the lower $\mathrm{pH}$ sites. Simpson et al. (1985) found that their most acidic sites (pH 4.4 to 5.0) contained fewer than half as many benthic taxa as the more neutral sites (pH 5.8 to 7.2); blackflies constituted a larger proportion of the community than in the higher $\mathrm{pH}$ streams. Sharpe et al. (1987) examined the benthic macroinvertebrates from eleven headwater streams in Pennsylvania with pH ranging from 4.29 to 7.12. Prosimulium spp. were found exclusively in the most acidic (zero alkalinity) streams. The general conclusion of these studies seems to be that only certain groups of insects are able to tolerate the lower $\mathrm{pH}$ ranges, thus the species richness decreases in those areas leaving niches for the more tolerant groups. It is clear that blackflies are more tolerant and able to take advantage of the resources abandoned by the less tolerant groups. Chmielewski and Hall (1992) showed that many blackfly species from Costello Creek could tolerate more severe ( $\mathrm{pH} 4.0$ and/or 3.5) short-term experimental $\mathrm{pH}$ depressions than had been measured during 1984-86 (greatest decrease, MC1-pH 4.9), thus corroborating many field surveys that blackflies are quite tolerant to elevated acidity.

Hall and Ide (1987) have shown that many of the more pH sensitive taxa of mayflies and stoneflies have disappeared from MC1 since the 1930s. It is possible that the extirpation of some of the more sensitive taxa has left available niches in which colonization of opportunistic blackflies occurred. Another possibility is that predators of blackflies may be adversely affected by lower $\mathrm{pH}$. Species in two genera of insects (Baetis and Isoperla) that are known to include predators of blackflies (Davies 1981) have disappeared from MC1 as a result of its acidification (Hall and Ide 1987). Thus, a possible mechanism that may have produced the increases in total blackfly abundance observed in the headwaters of MC1 is greater physiological tolerance than other taxa such as mayflies and stoneflies (Chmielewski and Hall 1992; Hall and Ide 1987). 
With the exception of $\mathrm{pH}$, there are no indications that water quality of Costello Creek and Mud Creek was different in 1984-86 than it was in 1937-47. Discharge, temperature and oxygen remain virtually unchanged from that reported by Ide (1940), Sprules (1947), and Davies (1950). In addition, metal levels are not elevated at the more acidic sites (Hall and Ide 1987 and Findeis et al. 1992). Furthermore, there are no indications that any physical characteristics of either stream have changed over the study period (Sprules 1947, Hall and Ide 1987). Our analyses suggest that acidity of these two streams is likely the main factor that may have changed over the past fifty years, although in the early studies $\mathrm{pH}$ data were scant. Readings were taken rarely and not necessarily during the spring runoff period. In addition, the colourimetric method used was inaccurate by today's standards (Kramer and Tessier 1982). However, the available data indicate that, on a relative scale, the $\mathrm{pH}$ ranges of all early study sites may have been similar to each other. According to available North American historical precipitation data, it is unlikely that the Algonquin Park area was receiving acidic deposition until after the early studies were completed (see Gorham 1976). In contrast, the $1984-86 \mathrm{pH}$ data clearly show pronounced depressions currently experienced by both creeks with the most severe depressions occurring at the headwaters of Mud Creek.

Regardless of what precautions are taken, different traps in different studies, in all probability, will not yield similar results especially when the studies were done intermittently over a span of 50 years with different collectors for almost every trap-year. Furthermore, some of the investigators have already applied different correction factors to their own results for gains and losses of small species through the mesh of the cage (Ide 1940, Sprules 1947 and Davies 1950) and for specimen losses when the traps were cleared once per day instead of hourly or twice hourly (Sprules 1947 and Hayton 1979). Sprules (1947) commented that it is not likely that the catches from his cages represented the absolute density of emergent insects but they were useful in a relative sense. Thus, any changes in blackfly densities observed between the studies using different traps probably will represent not absolute but rather relative differences between the acidified and non-acidified sites, the purpose of the present study. 
It is unfortunate that species level identifications were not available for the early $\mathrm{MC} 1$ and MC2 collections so that shifts in species composition could be related to the overall increases in abundance. The $\mathrm{pH}$ depressions of $\mathrm{MC} 3$ were less severe (to $\mathrm{pH}$ 5.11) and did not produce increases in blackfly abundance. In addition, given the large yearly fluctuations seen in many species in the control sites with only one pre-acidification year of data at MC3, it is difficult to draw any firm conclusions on the effect that lowered stream $\mathrm{pH}$ has had on species composition over time. Suffice to say that any changes in species composition at MC3 were much the same as the changes that occurred in the control sites but cannot be specifically attributed to changes in $\mathrm{pH}$. This includes the Shannon-Weiner indices of diversity which indicated an increase in diversity at all three sites. It is possible that the $\mathrm{pH}$ depressions were not severe enough at $\mathrm{MC} 3$ ( $\mathrm{pH}$ 5.11) to precipitate changes in species composition. However, comparisons of trap efficiency (cited in methods) point to an underestimate of species captured in cones relative to cages. Thus, our results in 1984-86 are likely underestimating the increase of species.

The nine years of data for $\mathrm{CC} 1$ where specific level identifications were available clearly demonstrate the variability in species composition that can occur at the same site over many seasons. Others have reported this same type of variability when blackfly populations were monitored over time (Colbo 1985, Gislason and Gardarsson 1988 and Ide unpubl.). Some explanations for the fluctuations were changes in discharge rate (Colbo 1985), fluctuations in primary production causing fluctuations in fine POM, amount and numbers of predators (Gislason and Gardarsson 1988) and late arrival of arctic spring (Ide unpubl.). Davis (1950) offered several possible explanations for the increase in blackfly densities in 1946 and 1947 including 1.) a more productive site, 2.) the use of finer mesh screening in the cages, and 3.) larger populations in the stream. The possibility that the treatment of the stream in 1944 with DDT had actually helped to increase blackfly numbers by 1946 was also discussed. However, after seeing Davies' (1950) data in conjunction with the other two studies, it is clear that his first conjecture, that moving the trap a few metres downstream apparently to a more productive site could increase the catch by at least an order of magnitude, was correct. 
A significant point to keep in mind is that thousands of kilometers of streams similar to MC1 exist on the Canadian Shield, perhaps producing orders of magnitude more blackflies than 50 years ago. In Algonquin Park alone, some areas have between 1,892 and 3,785 km of streams $<10 \mathrm{~m}$ in width per $\mathrm{km}^{2}$ of land, but a larger area of the park has more than $3,785 \mathrm{~km}$ of streams of the same order per $\mathrm{km}^{2}$ (Wickware and Rubec 1989). It is possible that many small first-order streams have not been included in this survey. Increased acidification of these small streams could cause a substantial increase in blackfly adults that could disperse over great distances (9-35 km, Baldwin et al. 1975) and affect tourism and wildlife in the park.

The current investigation involves the only North American long-term data set demonstrating changes in invertebrate biota accompanying increases in acidity of surface waters. Perhaps the short term variability observed in the blackfly populations in this study will provide the impetus to extend other studies until steady baselines are perceptible. Only then will the true consequences of chronic stresses such as anthropogenic acidification be realized.

\section{ACKNOWLEDGEMENTS}

We thank T. Champoux, S. David, J. Findeis, R. Gilbert, L. Heintz, R. Ingram and K. Ralph for assistance in the field. J. Findeis, B. Hutchinson, A. Nicolls and T. Pawson helped with computer graphics. M. Berrill, J.G. Chmielewski, L.D. Corkum, D.M. Davies, P. Dillon, N. Hutchinson, G. Mierle, K. Somers and N. Yan all made useful comments on early drafts of this manuscript. 


\section{REFERENCES}

Adler, P.H. 1988. Black flies are busting out all over. Natural History. 6: 34-40.

Baldwin, W.F., A.S. West and J. Gomery. 1975. Dispersal pattern on blackflies (Diptera: Simuliidae) tagged with ${ }^{32}$ P. Can. Ent. 107: 113-118.

Bell, H.L. 1971. Effect of low $\mathrm{pH}$ on the survival and emergence of aquatic insects. Wat. Res. 5: 313-319.

Bernard, D.P., W.E. Neill and L. Rowe. 1990. Impact of mild experimental acidification on short-term invertebrate drift in a sensitive British Columbia stream. Hydrobiol. 203: 63-72.

Boerger, H. 1981. Species composition, abundance and emergence phenology of midges (Diptera: Simuliidae) in a brown water stream of West-Central Alberta, Canada. Hydrobiol. 80: 7-30.

Chan, W.H., A.J.S. Tang and M.A. Lusis. 1983. Precipitation concentration and wet deposition fields of pollutants in Ontario, Sept. 1980 to Dec. 1981. p 1-41. Ontario Ministry of the Environment, APIOS Report ARB-74-84-ARSP, Toronto, Ontario.

Chmielewski, C.M. and R.J. Hall. 1992. Response of immature blackflies (Diptera: simuliidae) to experimental pulses of acidity. Can. J. Fish. Aquat. Sci. 49: 883-840.

Cogbill, C.V. 1976. The history and character of acid precipitation in eastern North America. Wat. Air and Soil Pollut. 6: 407-413.

Colbo, M.H. 1985. Variation in larvae black fly populations at three sites in a stream system over five years (Diptera: Simuliidae). Hydrobiol. 121: 77-82. 
Davidson, A., L. Nadeau, G.M. Grant and L.L. Pryer. 1985. Studies in the Greenville Region Province of Ontario, p. 463-483. In: Current Research Part A. Geol. Surv. Can. Pap. 85-1A.

Davies, D.M. 1949. The ecology and life history of blackflies (Simuliidae: Diptera) in Ontario with a description of a new species. PhD Thesis, McMaster University, Hamilton, Ontario.

Davies, D.M. 1950. A study of the blackfly populations of a stream in Algonquin Park, Ontario. Trans. R. Can. Inst. 59: 121-160.

Davies, D.M. 1981. Predators upon blackflies. In: Blackflies: the future for biological methods in integrated control. M. Laird (ed). Academic Press, New York and London. pp. 139-158.

Davies, I.J. 1984. Sampling aquatic insect emergence. In: A manual on methods for the assessment of secondary productivity in fresh waters. J.A. Downing and F.H. Rigler (eds.) Blackwell Scientific Publications. London. pp 161-227.

Findeis, J.G., R.J. Hall, F.P. Ide, M. Coleman Taylor and A. Nicolls. 1992. Biological and chemical data summary for Costello Creek and Mud Creek located in Algonquin Provincial Park. Ontario Ministry of the Environment Data Report, in press.

Giberson, D.J. and R.J. MacKay. 1991. Life history and distribution of mayflies (Ephemeroptera) in some acid streams in south central Ontario, Canada. Can. J. Zool. 69: 899-910.

Gislason, G.M. and Gardarsson, A. 1988. Long-term studies on Simulium vittatum zett. (Diptera: Simuliidae) in the River Laxa, North Iceland, with particular reference to different methods used in assessing population changes. Verh. Internat. Verein. Limnol. 23: 2179-2188. 
Gorham, E. 1976. Acid precipitation and its influence upon aquatic ecosystems -- an overview. Water, Air, Soil Pollut. 6: 457-481.

Gorham, E., S.E. Bayley and D.W. Schlinder. 1984. Ecological effects of acid deposition upon peatlands: a neglected field in "acid-rain" research. Can. J. Fish. Aquat. Sci. 41: 1256-1268.

Hall, R.J., R.C. Bailey and J. Findeis. 1988. Factors affecting survival and cation concentration in the blackflies Prosumulim fuscum/mixtum and the mayfly Leptophlebia cupida during spring snowmelt. Can. J. Fish. Aquat. Sci. 45: 2123-2132.

Hall, R.J. and J.P. Ide. 1987. Evidence of acidification effects on stream insect communities in central Ontario between 1937 and 1985. Can. J. Fish. Aquat. Sci. 44: 1652-1657.

Hall, R.J., G.E. Likens, S.B. Fiance and G.R. Hendry. 1980. Experimental acidification of a stream in the Hubbard Brook Experimental Forest, New Hampshire. Ecol. 61: 976-989.

Hayton, A. 1979. The age structure and population dynamics of some black-flies in Algonquin Park, Ontario. MSc. Thesis, University of Waterloo, Waterloo, Ontario.

Hildrew, A.G., C.R. Townsend and J. Francis. 1984. Community structure in some southern English streams: The influence of species interactions. Freshwat. Biol. 14: 297-310.

Hopkins, P.S., K.W. Kratz and S.D. Cooper. 1989. Effects of an experimental acid pulse on invertebrates in a high altitude Sierra Nevada stream. Hydrobiol. in press.

Ide, F.P. 1940. Quantitative determination of the insect fauna of rapid water. University of Toronto Studies, Biol. Ser. 47. Pub. Ont. Fish. Res. Lab. LIX. 
Kimmerle, R.A. and N.H. Anderson. 1967. Evaluation of aquatic emergence traps. J. Econ. Entomol. 60(5): 1255-1259.

Kramer, J. and A. Tessier. 1982. Acidification of aquatic systems: A critique of chemical approaches. Envir. Sci. Technol. 16: 606A-615A.

LaZerte, B. 1984. Forms of aqueous aluminum in acidified catchments of Southern Ontario: A methodological analysis. Can. J. Fish. Aquat. Sci. 41: 766-776.

Likens, G.E. 1983. A priority for ecological research. Bull Ecolog. Soc. Am. 64: 234-243.

Locke, B.A., and L.D. Scott. 1986. Ontario Ministry of the Environment Data Report DR 86/4: $80 \mathrm{pp}$.

MacKay, R.J. and K.E. Kersey. 1985. A preliminary study of aquatic insect communities and leaf decomposition in acid streams near Dorset, Ontario. Hydrobiol. 122: 3-11.

Minshall, G.W. and J.N. Minshall. 1978. Further evidence on the role of chemical factors in determining the distribution of benthic invertebrates in the River Duddon. Arch. Hydrobiol. 83: 324-355.

Ontario Ministry of the Environment. 1984. Cumulative (28d) precipitation chemistry Jan. 5, 1982 - Jan. 4, 1983. APIOS Report ARB 56-84-ARSP, Toronto, Ontario. 60 pp.

Ontario Ministry of the Environment. 1986. APIOS Report ARB-85-AQM, Toronto, Ontario. $172 \mathrm{pp}$.

Raddum, G.G. and A. Fjellheim. 1984. Acidification and early warning organisms in freshwater in Western Norway. Appl. Limnol. 2: 1973-1980. 
Resh, V.H. and J.D. Unzicker. 1975. Water quality monitoring and aquatic organisms: the importance of species identification. Water Quality Monitoring 47: 9-19.

Ross, D.H. and R.W. Merritt. 1987. Factors affecting larval black fly distributions and population dynamics. In: Black flies. Ecology, population management and annotated world list. K.C. Kim and R.W. Merritt (eds.). Pennsylvania State University, Penn. pp. 90-108.

Savage, J. 1949. Aquatic invertebrates: mortality due to DDT and subsequent reestablishment. Dep. Lands For. Ont. Div. Res. Biol. Bull. 2: 39-47.

Scheider, W.A. 1978. Applicability of phosphorous budget models to small Precambrian lakes, Algonquin Park, Ontario. J. Fish. Res. B. Can. 35: 300-304.

Schindler, D.W. 1987. Detecting ecosystem responses to anthropogenic stress. Can. J. Aquat. Sci. 44: 6-25.

Scott, W. and D.F. Opdyke. 1941. The emergence of insects from Winona Lake. Invest. Ind. Lakes. 2: 3-14.

Sharpe, W.E., T.G. Perlic, W.M. Tzilkowski and W.G. Kimmel. 1987. Status of headwater benthic insect populations in an area of high hydrogen ion and sulfate deposition. Northeastern Environmental Science 6: 23-30.

Simpson, K.W., R.W. Bode, and J.R. Colquhoun. 1985. The macroinvertebrate fauna of an acid-stressed headwater stream system in the Adirondack Mountains, New York. Freshwat. Biol. 15: 671-681.

Sprules, W.M. 1947. An ecological investigation of stream insects in Algonquin Park, Ontario. Univ. Toronto Stud. Biol. Ser. 56: 1-81. 
Stoner, J.H., A.S. Gee and K.R. Wade. 1984. The effects of acidification on the ecology of streams in the upper Tywi catchment in West Wales. Environ. Pollut. A (35): 125157.

Strayer, D., J.S. Glitzenstein, C.G. Jones, J. Kolasa, G.E. Likens, M.J. McDonnell, G.G. Parker and S.T.A. Pickett. 1986. Long-term ecological studies: An illustrated account of their design, operation, and importance to ecology. Occasional Publication, Institute of Ecosystem Studies, The New York Botanical Garden, Millbrook, N.Y., No. 2, 38 pp.

Sutcliffe, D.W. and T.R. Carrick. 1973. Studies on mountain streams in the English Lake District I. pH, calcium and the distribution of invertebrates in the River Duddon. Freshwat. Biol. 3: 437-462.

Wetzel, R.G. and G.E. Likens. 1991. Limnological Analyses. W.B. Saunders Company, Toronto. $357 \mathrm{pp}$.

Wickware, G.M. and C.D.A. Rubec. 1989. Ecoregions of Ontario. Ecological Land Classification Series No. 26. Sustainable Development Branch, Environment Canada. Ottawa, Ontario. $37 \mathrm{pp}$. 


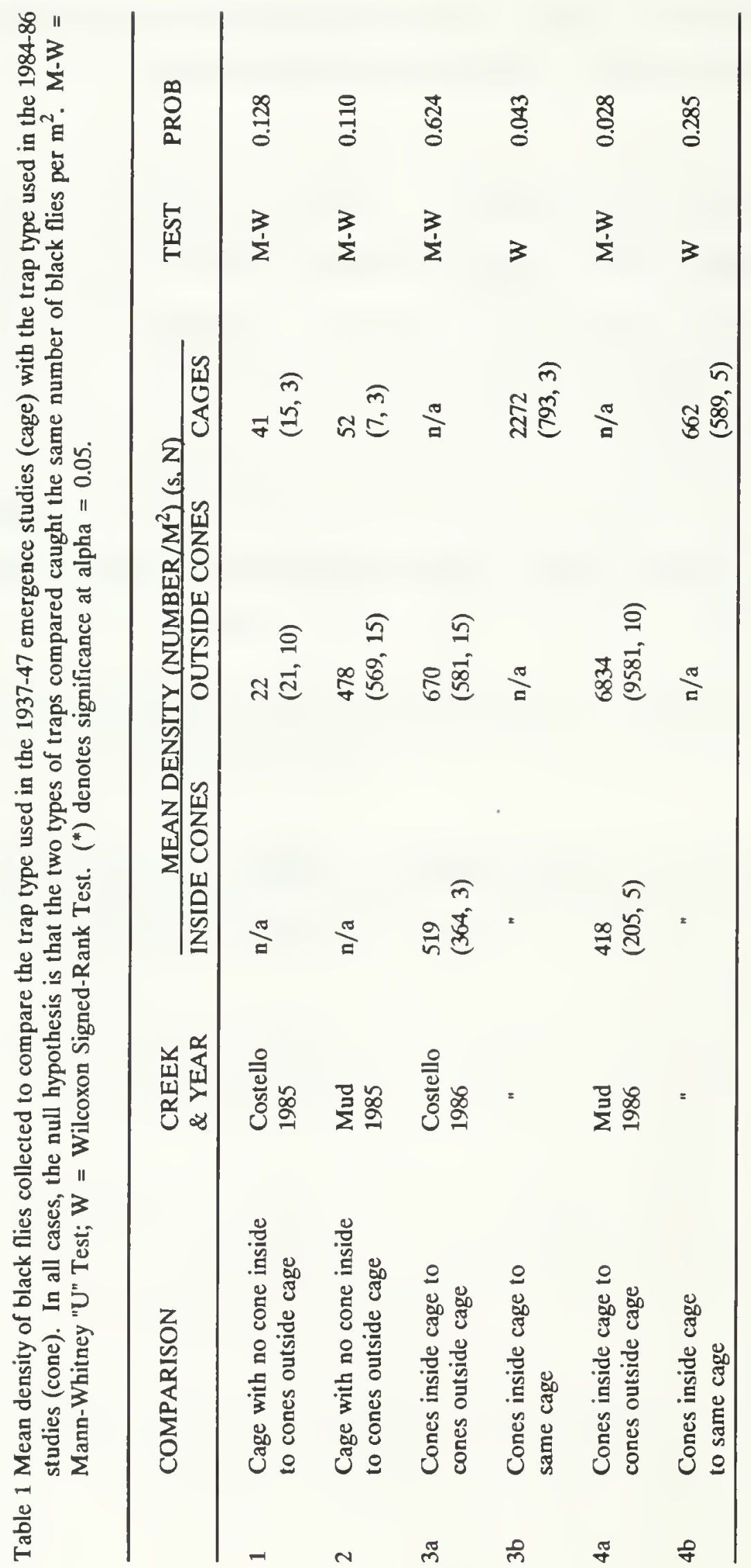


Table 2 Total numbers (mean number $/ \mathrm{m}^{2} \pm$ S.E.), percent composition (in parentheses) and diversity indices for 14 species of blackflies collected in emergence traps in Costello Creek 1 (CC1) from 1937 - 1986. Total numbers were available only for 1937. Percent composition was not calculated for 1938 because all the species were not available.

\begin{tabular}{|c|c|c|c|c|c|c|c|c|c|c|c|}
\hline Species & 1937 & 1938 & 1939 & 1940 & 1941 & 1942 & 1943 & 1975 & 1984 & 1985 & 1986 \\
\hline Cnephia dacotensis & & $\begin{array}{r}3.6 \\
(<1)\end{array}$ & $\begin{array}{l}18 \\
(3)\end{array}$ & $\begin{array}{l}1198 \\
(35)\end{array}$ & $\begin{array}{r}1.2 \\
(<1)\end{array}$ & $\begin{array}{r}835 \\
(72)\end{array}$ & $\begin{array}{r}244 \\
(3)\end{array}$ & $\begin{array}{r}94 \\
(3)\end{array}$ & $\begin{array}{r}375 \pm 167 \\
(19)\end{array}$ & $\begin{array}{r}0 \\
(0)\end{array}$ & $\begin{array}{r}205 \pm 85 \\
(12)\end{array}$ \\
\hline Simulium euryadminiculum & & $\begin{array}{r}477 \\
(40.8)\end{array}$ & $\begin{array}{r}388 \\
(72)\end{array}$ & $\begin{array}{r}798 \\
(24)\end{array}$ & $\begin{array}{r}84 \\
(45)\end{array}$ & $\begin{array}{r}0 \\
(0)\end{array}$ & $\begin{array}{r}178 \\
(2)\end{array}$ & $\begin{array}{r}35 \\
(<1)\end{array}$ & $\begin{array}{r}0 \\
(0)\end{array}$ & $\begin{array}{r}0 \\
(0)\end{array}$ & $\begin{array}{r}0 \\
(0)\end{array}$ \\
\hline S. venustum & & $\begin{array}{r}72 \\
(6)\end{array}$ & $\begin{array}{r}12 \\
(2)\end{array}$ & $\begin{array}{r}467 \\
(14)\end{array}$ & $\begin{array}{r}0 \\
(0)\end{array}$ & $\begin{array}{r}45 \\
(4)\end{array}$ & $\begin{array}{l}201 \\
(3)\end{array}$ & $\begin{array}{r}3362 \\
(48)\end{array}$ & $\begin{array}{r}290 \pm 83 \\
(22)\end{array}$ & $\begin{array}{r}64 \pm 10 \\
(9)\end{array}$ & $\begin{array}{r}42 \pm 14 \\
(4)\end{array}$ \\
\hline S. verecundum & & 0 & $\begin{array}{r}54 \\
(10)\end{array}$ & $\begin{array}{r}275 \\
(8)\end{array}$ & $\begin{array}{r}0 \\
(0)\end{array}$ & $\begin{array}{r}95 \\
(8)\end{array}$ & $\begin{array}{r}28 \\
(<1)\end{array}$ & $\begin{array}{r}1121 \\
(18)\end{array}$ & $\begin{array}{r}46 \pm 20 \\
(3)\end{array}$ & $\begin{array}{r}36 \pm 8 \\
(4)\end{array}$ & $\begin{array}{r}431 \pm 108 \\
(30)\end{array}$ \\
\hline Stegoptema mutata & & $\begin{array}{r}205 \\
(17.5)\end{array}$ & $\begin{array}{l}9.6 \\
(2)\end{array}$ & $\begin{array}{r}7.2 \\
(<1)\end{array}$ & $\begin{array}{l}6.0 \\
(3)\end{array}$ & $\begin{array}{r}12 \\
(1)\end{array}$ & $\begin{array}{l}178 \\
(2)\end{array}$ & $\begin{array}{l}206 \\
(5)\end{array}$ & $\begin{array}{r}894 \pm 495 \\
(29)\end{array}$ & $\begin{array}{r}275 \pm 71 \\
(23)\end{array}$ & $\begin{array}{r}423 \pm 104 \\
(27)\end{array}$ \\
\hline Prosimulium fuscum & & $\begin{array}{r}214 \\
(18.3)\end{array}$ & $\begin{array}{r}31 \\
(6)\end{array}$ & $\begin{array}{r}399 \\
(12)\end{array}$ & $\begin{array}{r}43 \\
(23)\end{array}$ & $\begin{array}{r}8.4 \\
(<1)\end{array}$ & $\begin{array}{l}6087 \\
(78)\end{array}$ & $\begin{array}{r}645 \\
(13)\end{array}$ & $\begin{array}{r}545 \pm 195 \\
(22)\end{array}$ & $396 \pm 123$ & $194 \pm 161$ \\
\hline$P$. mixtum & & $\begin{array}{r}184 \\
(15.7)\end{array}$ & $\begin{array}{r}14 \\
(3)\end{array}$ & $\begin{array}{l}148 \\
(4)\end{array}$ & $\begin{array}{r}0 \\
(10)\end{array}$ & $\begin{array}{r}0 \\
(0)\end{array}$ & $\begin{array}{r}754 \\
(10)\end{array}$ & $\begin{array}{r}0 \\
(0)\end{array}$ & $\begin{array}{r}107 \pm 80 \\
(4)\end{array}$ & $\begin{array}{r}471 \pm 181 \\
(29)\end{array}$ & $\begin{array}{r}162 \pm 54 \\
(9)\end{array}$ \\
\hline C. omithophilia & & - & (0) & $(0)$ & (0) & (0) & $(0)$ & $\begin{array}{l}17 \pm 2 \\
(<1)\end{array}$ & $\begin{array}{r}0 \\
(0)\end{array}$ & $\begin{array}{r}0 \\
(0)\end{array}$ & $\begin{array}{r}0 \\
(0)\end{array}$ \\
\hline Simulium aureum & & - & $\begin{array}{r}1.2 \\
(<1)\end{array}$ & $\begin{array}{r}1.2 \\
(<1)\end{array}$ & $\begin{array}{r}0 \\
(0)\end{array}$ & $\begin{array}{r}2.4 \\
(<1)\end{array}$ & $\begin{array}{r}0 \\
(0)\end{array}$ & $\begin{array}{r}24 \\
(<1)\end{array}$ & $\begin{array}{r}7.3 \pm 3.6 \\
(<1)\end{array}$ & $\begin{array}{r}23 \pm 11 \\
(3)\end{array}$ & $\begin{array}{r}23 \pm 10 \\
(1)\end{array}$ \\
\hline S. congareenanum & & - & (0) & (0) & (0) & (0) & (0) & (0) & $\begin{array}{r}0 \\
(0)\end{array}$ & $\begin{array}{r}8.7 \pm 4.2 \\
(<1)\end{array}$ & $\begin{array}{r}7.3 \pm 6.9 \\
(<1)\end{array}$ \\
\hline S. decorum & & $\begin{array}{r}1.2 \\
(<1)\end{array}$ & $\begin{array}{l}6.0 \\
(1)\end{array}$ & $\begin{array}{r}3.4 \\
(<1)\end{array}$ & $\begin{array}{r}10.8 \\
(6)\end{array}$ & $\begin{array}{r}20 \\
(2)\end{array}$ & $\begin{array}{r}2.4 \\
(<1)\end{array}$ & $\begin{array}{r}3.5 \\
(<1)\end{array}$ & $\begin{array}{r}1.8 \pm 1.7 \\
(<1)\end{array}$ & $\begin{array}{r}4.3 \pm 2.1 \\
(<1)\end{array}$ & $\begin{array}{r}29 \pm 9 \\
(2)\end{array}$ \\
\hline S. rugglesi & & - & $\begin{array}{r}0 \\
(0)\end{array}$ & $\begin{array}{r}0 \\
(0)\end{array}$ & $\begin{array}{r}0 \\
(0)\end{array}$ & $\begin{array}{r}0 \\
(0)\end{array}$ & $\begin{array}{r}0 \\
(0)\end{array}$ & $\begin{array}{r}0 \\
(0)\end{array}$ & $\begin{array}{r}3.6 \pm 2.2 \\
(<1)\end{array}$ & $\begin{array}{r}8.7 \pm 4.2 \\
(0)\end{array}$ & $\begin{array}{r}7.3 \pm 6.9 \\
(0)\end{array}$ \\
\hline S. tuberosum & & $\begin{array}{r}2.4 \\
(<1)\end{array}$ & $\begin{array}{r}3.6 \\
(<1)\end{array}$ & $\begin{array}{r}84 \\
(3)\end{array}$ & $\begin{array}{r}12 \\
(7)\end{array}$ & $\begin{array}{r}127 \\
(11)\end{array}$ & $\begin{array}{r}41 \\
(<1)\end{array}$ & $\begin{array}{r}474 \\
(12)\end{array}$ & $\begin{array}{r}3.6 \pm 2.2 \\
(<1)\end{array}$ & $\begin{array}{r}4.4 \pm 2.1 \\
(1)\end{array}$ & $\begin{array}{r}19 \pm 7 \\
(2)\end{array}$ \\
\hline S. vemum & & - & $\begin{array}{r}3.6 \\
(<1)\end{array}$ & $\begin{array}{r}2.4 \\
(<1)\end{array}$ & $\begin{array}{r}0 \\
(0)\end{array}$ & $\begin{array}{r}3.6 \\
(<1)\end{array}$ & $\begin{array}{r}23 \\
(<1)\end{array}$ & $\begin{array}{r}7.0 \\
(<1)\end{array}$ & $\begin{array}{r}5.5 \pm 2.5 \\
(<1)\end{array}$ & $\begin{array}{r}0 \\
(0)\end{array}$ & $\begin{array}{r}19 \pm 9 \\
(<1)\end{array}$ \\
\hline S. vittatum & & $\begin{array}{r}8.4 \\
(<1)\end{array}$ & $\begin{array}{r}2.4 \\
(<1)\end{array}$ & $\begin{array}{r}1.2 \\
(<1)\end{array}$ & $\begin{array}{r}1.2 \\
(<1)\end{array}$ & $\begin{array}{r}12 \\
(1)\end{array}$ & $\begin{array}{r}85 \\
(1)\end{array}$ & $\begin{array}{r}31 \\
(<1)\end{array}$ & $\begin{array}{r}3.6 \pm 2.2 \\
(<1)\end{array}$ & $\begin{array}{r}0 \\
(0)\end{array}$ & $\begin{array}{r}50 \pm 17 \\
\text { (3) }\end{array}$ \\
\hline
\end{tabular}

Total Number

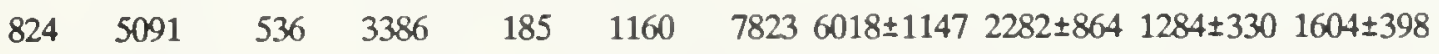
Shannon-Weiner $\mathbf{H}$

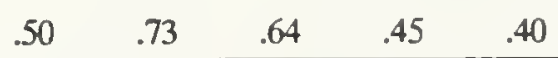
.67 .73 .70 .81 
Table 3

Total numbers (mean number $/ \mathrm{m}^{2}$ ), percent composition (in parentheses) and diversity indices for 13 species of blackflies in Costello Creek, Station 2 (CC2) from 1946 - 75. One trap was used during each year.

Species

Cnephia dacotensis

C. omithophilia

Simulium oureum

S. deconum

S. euryadminiculum

S. tuberosum

S. venustum

S. verecundum

S. vernum

S. vittatum

Stegoptema mutata

Prosimulium fuscum

P. mixtum

Total Numbers

Shannon-Weiner H
1946

3.6

(<1)

0

(0)

105

(<1)

2453

(10)

0

(0)

237

(1)

10,059

(42)

919

(4)

18

(<1)

9914

(42)

2.4

(<1)

0
$(0)$

(0)

0

(0)

23,710

.51
1947

4226

(6)

0
$(0)$

(0)

538

(<1)

8151

(12)

1975

588

(2)

56

(<1)

56
$(<1)$

112

(<1)

63

(<1)

(0)

2856

(2) (10)

15,528

(23)

10,340

(37)

5432

(20)

(50)

140

(<1)

321
$(<1)$

343

4157

(6)

(1)

1253

(5)

$(<1)$

6354

(5)

(<1)

0

(0)

(<1)

27,593

68,563

.71 
Table 4

Total numbers (mean number $/ \mathrm{m}^{2}$ ), percent composition (in parentheses) and diversity indices for 18 species of blackflies collected in emergence traps from Mud Creek, Station 3 (MC3). One trap was used in 1947 and 10 traps in 1985 and 1986, respectively.

Species

Cnephia dacotensis

C. invenusta

C. omithophilia

Simulium aureum

S. craxtoni

S. deconum

S. euryadminiculum

S. excisum

S. quebeceuse

S. tuberosum

S. venustum

S. verecundum

S. vemum

S. vittatum

Stegoptema mutata

Prosimulium fontanum

P. fuscum

P. mixtum

Total numbers

Shannon-Weiner $\mathbf{H}$
1947

1985

1986

(0)

10.2

(2)

1.5

(0) $\quad(<1)$

(0)

7.3

(0) (1)

(0)

$\begin{array}{ll}- & 2.9 \\ & \end{array}$

(<1)

61
$(4)$

1.2

$(<1)$

1.5

$(<1)$

(1)

1.2

4.4

(<1)

95
$(5)$

2.4

$(<1)$

(0)

(0)

1.2

$(<1)$

1.5

$(<1)$

(0)

3.6

(<1)

(0)

(0)

31

(3)

2.9

111

$(<1)$

(6)

658

(64)

99

(18)

287

(17)

$2.4 \quad 10.2$

(<1)

(2)

855

(50)

73

(7)

4.4

$(<1)$

47

(3)

39

(0)

(0)

102

(10)

188

(34)

134

(8)

22

(2)

(14)

29

(2)

33

(3)

48

(9)

13

(<1)

102

(10)

(17)

26

(2) 
Figure 1 Map of study sites on Costello Creek and Mud Creek, Algonquin Park, Ontario.

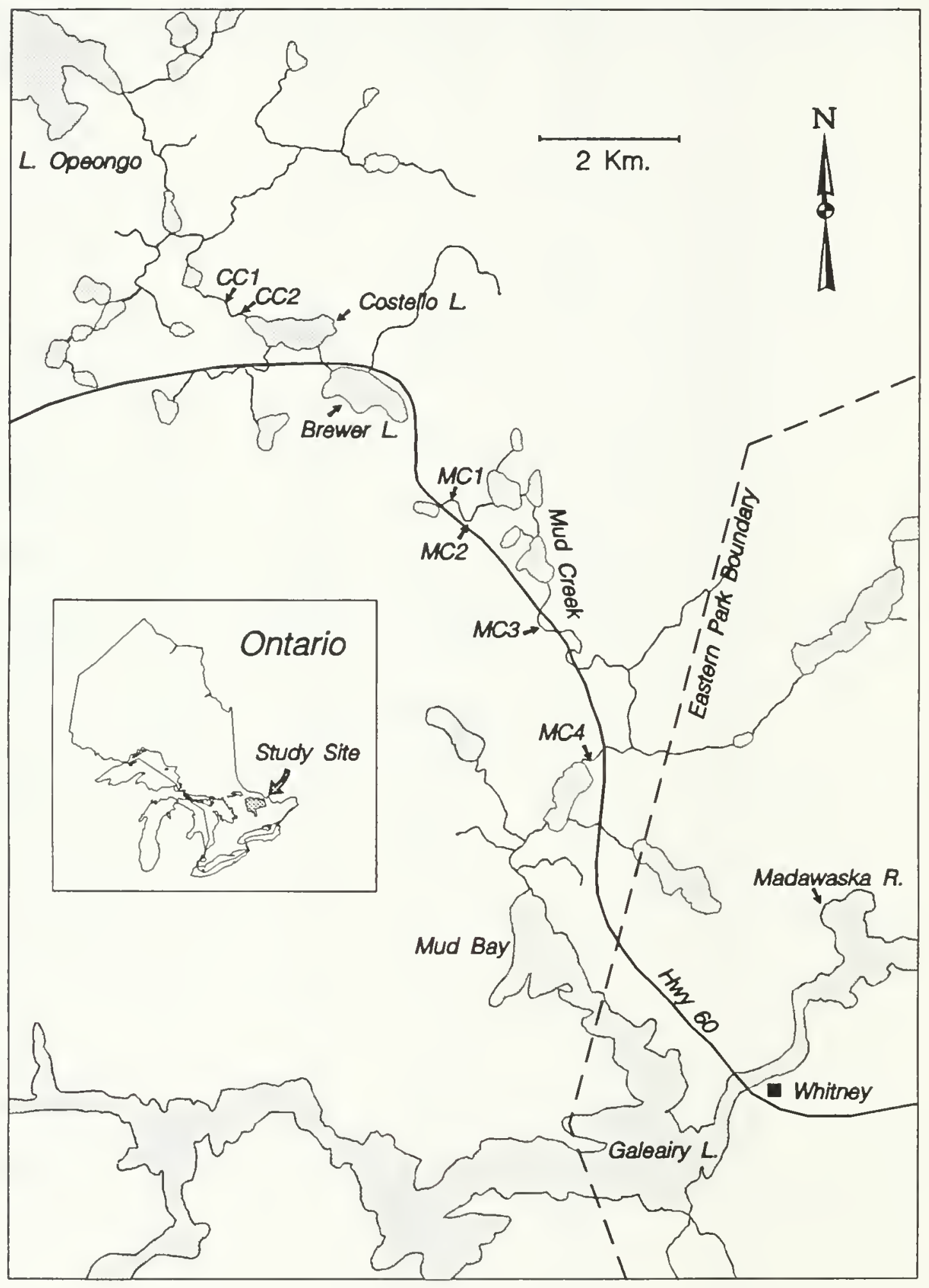


Figure 2 The three emergence traps used for blackfly collections from Costello Creek and Mud Creek, Algonquin Park, Ontario.
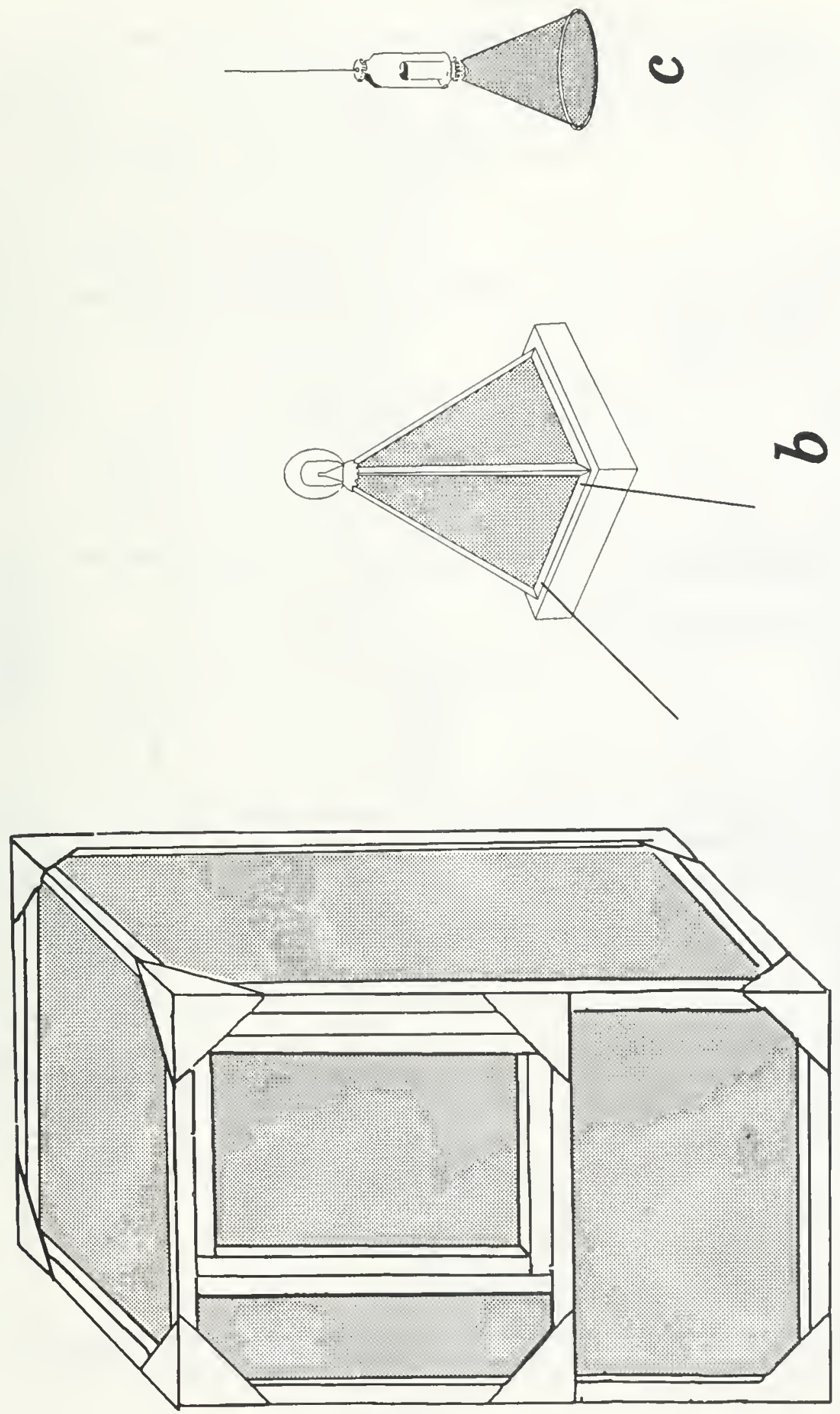
Figure $3 \mathrm{pH}$ measurements (1984-86) from Costello Creek and Mud Creek, Algonquin Park, Ontario.

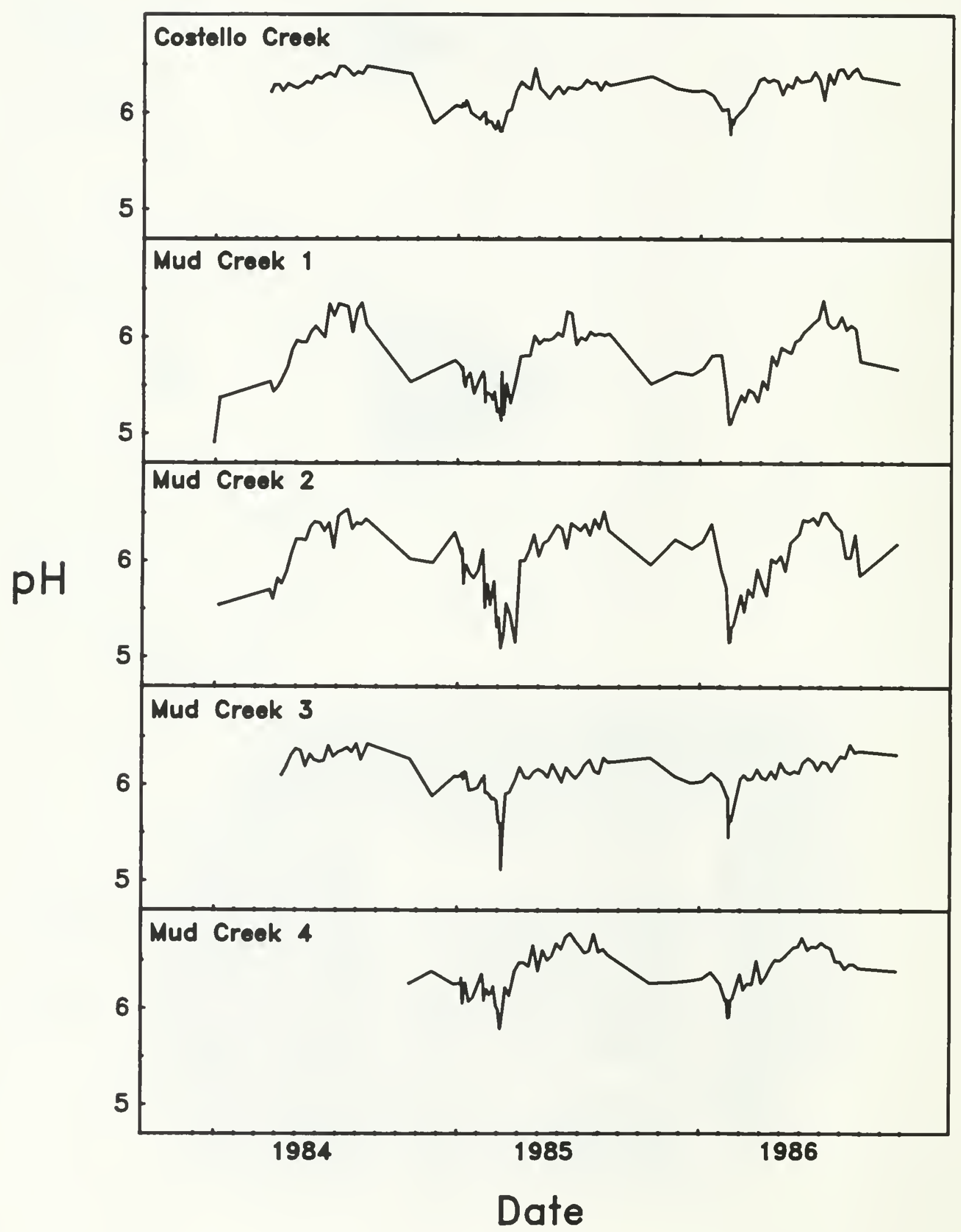


Figure 4 Discharge readings (1984-86) from Costello Creek and Mud Creek, Algonquin Park, Ontario.

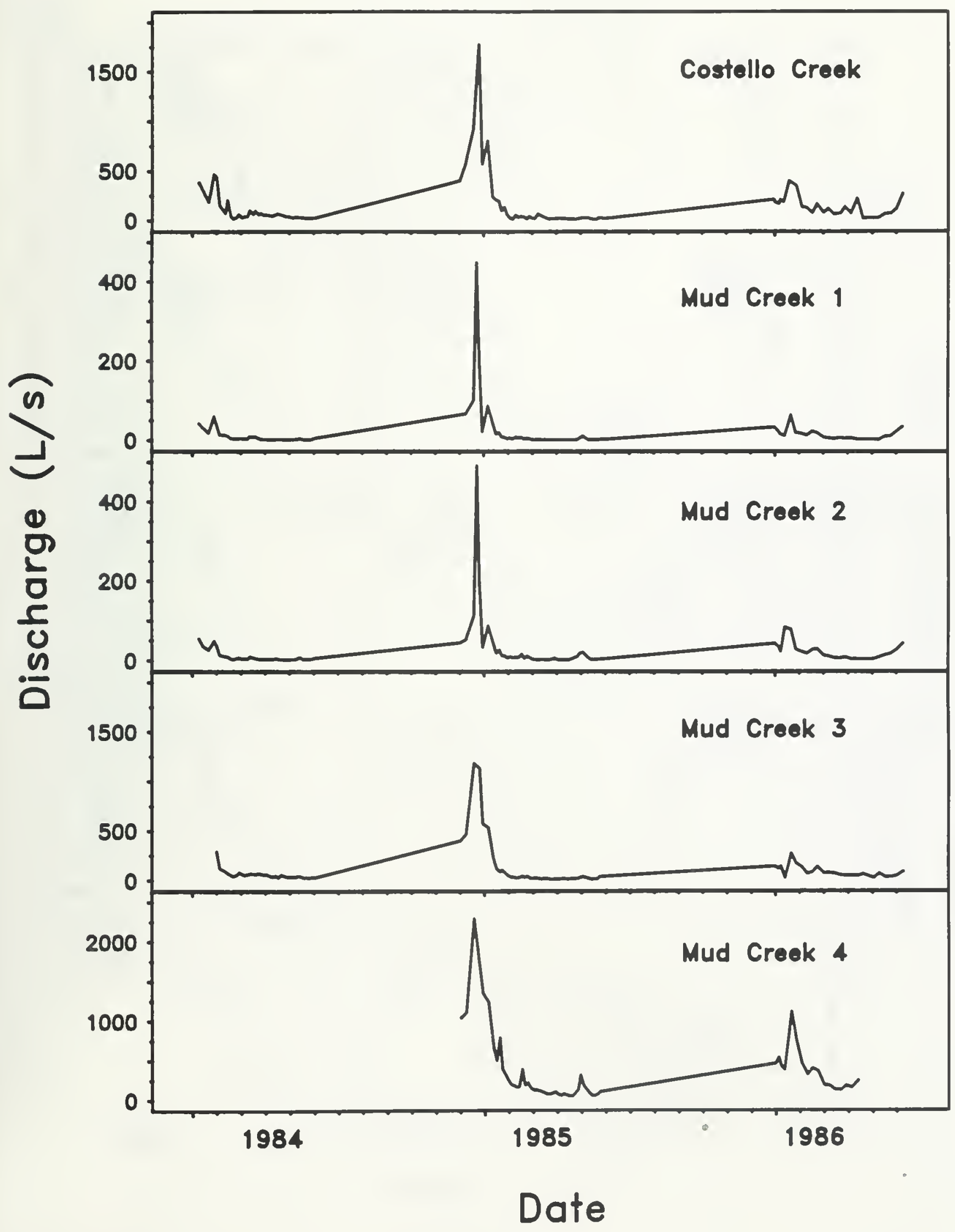


Figure 5 Temperature readings (1984-86) from Costello Creek and Mud Creek, Algonquin Park, Ontario.

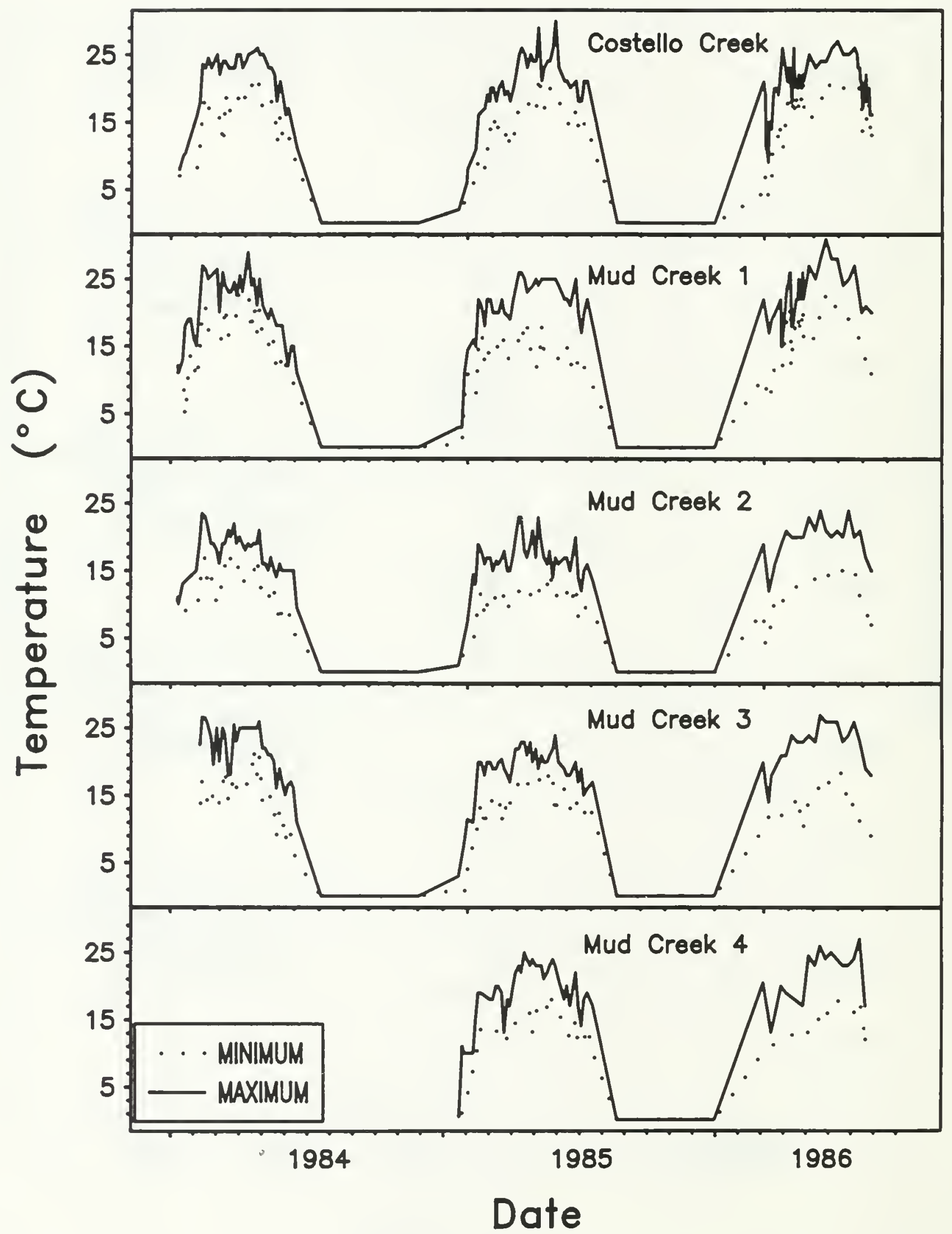


Figure $6 \mathrm{a}, 6 \mathrm{~b}$

Total numbers of blackflies emerging per $\mathrm{m}^{2}$ per year in Costello Creek ( $\mathrm{CC} 1$ and 2) and Mud Creek (MC1-4), Algonquin Park, Ontario.

\section{COSTELLO CREEK}

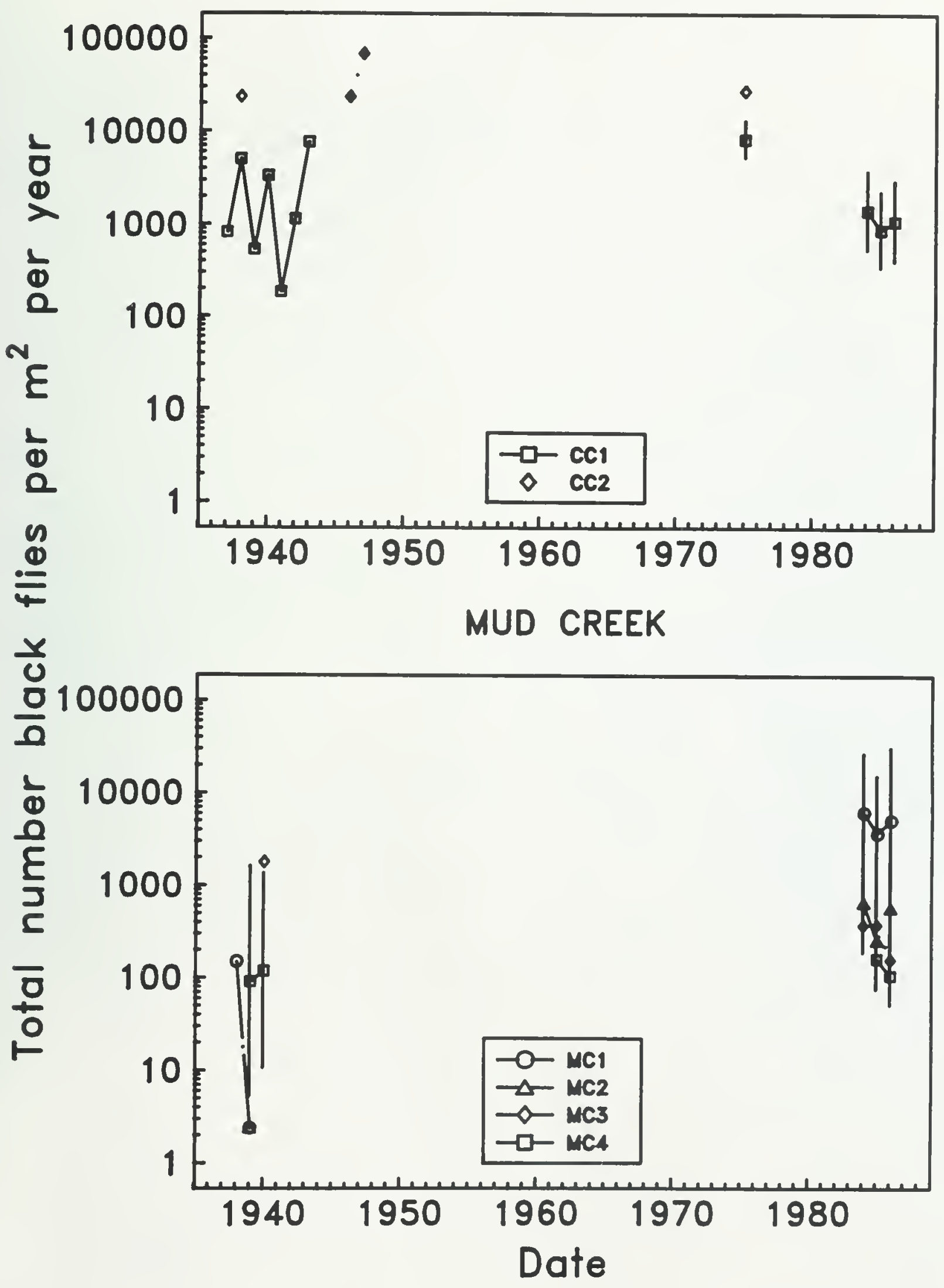



